\title{
PENGARUH SIKAP, NORMA SUBYEKTIF DAN KONTROL PERILAKU YANG DIRASAKAN TERHADAP NIAT BELI PUPUK PETROGANIK DI KABUPATEN BOYOLALI
}

\author{
Novitasari Dika Kusuma Dewi, Eny Lestari, Heru Irianto \\ Program Studi Agribisnis, Fakultas Pertanian, Universitas Sebelas Maret Surakarta \\ Jalan Ir. Sutami No. 36 A Kentingan Surakarta 57126 Telp./Fax (0271) 637457 \\ E-mail: novitasaridicka@student.uns.ac.id
}

\begin{abstract}
This research aims to find out the effects of product attributes, environmental awareness, the cost of fertilizer usage, subjective norms to the attitude of Petroganik fertilizer purchases also to find out the effects of attitude, subjective norms and cost of fertilizer usage to the intentions of purchasing Petroganik fertilizer. The method used in this research is explanatory methods by using survey techniques. Method taken to determine research location was conducted purposively and this research is done in Nogosari District and Musuk District. The method used for gathering samples with multi stage random sampling. Samples in this research were collected from 64 respondents split from 4 villages and 8 group farmers. The technique of collecting data was solved through observation, interviews, and logging. The analysis of the sample data used for this research is Structural Equation Models (SEM) method and also Partial Least Square (PLS) as an altiernative method. The research finds that (1) product attributes and environmental awareness positively determinants of purchase attitudes. (2) subjective norms, purchase attitudes, and cost of fertilizer usage affects the purchase intentions for Petroganik fertilizer.
\end{abstract}

Keywords: The Intention of Purchasing, Partial Least Square (PLS), Petroganik Fertilizer, Theory of Planned Behavior (TPB)

\begin{abstract}
Abstrak: Penelitian ini bertujuan untuk mengetahui pengaruh atribut produk, kesadaran lingkungan, biaya penggunaaan pupuk dan norma subyektif terhadap sikap pembelian pupuk petroganik serta untuk mengetahui pengaruh sikap pembelian pupuk petroganik, norma subyektif dan biaya penggunaan pupuk terhadap niat beli pupuk petroganik. Lokasi penelitian ditentukan secara sengaja (purposive) di Kecamatan Nogosari dan Kecamatan Musuk Kabupaten Boyolali. Penentuan Sampel ditentukan secara bertahap (multistage random sampling) dengan jumlah total responden sebesar 64 petani di 4 desa dan 8 kelompok tani di Kecamatan Nogosari dan Kecamatan Musuk. Analisis data dalam penelitian ini menggunakan Partial Least Square (PLS) untuk mengetahui pengaruhi dari masing-masing variabel. Hasil Penelitian menunjukkan bahwa atribut produk dan kesadaran lingkungan berpengaruh positif terhadap sikap pembelian pupuk petroganik dan norma subyektif, sikap pembelian dan biaya penggunaan pupuk berpengaruh terhadap niat pembelian pupuk petroganik.
\end{abstract}

Kata kunci: Niat Beli, Partial Least Square (PLS), Pupuk Petroganik, Theory of Planned Behavior (TPB)

\section{PENDAHULUAN}

Indonesia merupakan negara agraris yang sebagian besar penduduknya bekerja di sektor pertanian. salah satu faktor produksi yang berperan penting di sektor pertanian adalah lahan atau tanah. Kondisi tanah di lahan kering maupun di lahan sawah memiliki kandungan 
bahan organik yang rendah yaitu kurang dari 2\% (Purna, 2010). Hal tersebut dapat menurunkan sifat fisik dan kimia tanah atau biasa disebut kelelahan lahan (land fatigue) yang dapat menyebabkan penurunan kualitas dan sumberdaya lahan dan penurunan produktivitas (Elviwirda, 2015).

Pupuk organik merupakan pupuk pembenah tanah yang paling baik di bandingkan bahan pembenah sintetis. Hal inii dikarenakan pupuk organik dapat mensuplai bahan organik kedalam tanah yang dapat memperbaiki sifat fisik, kimia dan biologi tanah (Sutanto, 2002). Sebagai upaya untuk memperbaiki sifat fisik, kimia dan biologi tanah, pemerintah memberikan rekomendasi kepada petani untuk menggunakan pupuk organik dengan memberikan subsidi pupuk organik kesaman (Purna, 2010).

Rekomendasi pemerintah tersebut di apresiasi baik oleh petani, hal ini terlihat pada penjualan pupuk organik kemasan di Indonesia mengalami peningkatan sebesar $53 \%$ pada tahun 2010-2013 (PT Pupuk Indonesia, 2015). Peningkatan penjualan pupuk organik kemasan bersubsidi dikarenakan meningkatnya kesadaran dan pengetahuan petani terhadap pentingnya penggunaan dan manfaat pupuk organik. Namun penjualan pupuk organik kemasan (pupuk petroganik) di Kabupaten Boyolali mengalami fluktuatif. Penjualan pupuk petroganik yang fluktuatif terjadi di tingkat distributor dan penjualan pertahun. Hal ini mengindikasikan bahwa sikappetani terhadap pupuk petroganik belum konsisten, sehingga perlu dilakukan analisis perilaku untuk mengetahui karakteristik kebutuhan petani.Analisis perilaku konsumen dapat digunakan sebagai referensi untuk merumuskan strategi pemasaran (Setiadi, 2013).

Niat merupakan prediktor terdekat dari suatu perilaku. Niat individu dalam berperilaku di pengaruhi oleh sikap, norma subyektif dan kontrol perilaku yang dirasakan (Ajzen, 1991). Dengan demikian, penelitian ini mengukur niat beli petani terhadap pupuk petroganik dengan menggunakan variabel sikap pembelian pupuk petroganik, norma subyektif dan biaya penggunaan pupuk untuk mengukur kontrol perilaku yang dirasakan. Sikap pembelian pupuk petroganik dipengaruhi oleh atribut produk dan kesadaran terhadap lingkungan.
Berdasarkan latar belakang tersebut tujuan dalam penelitian ini untuk mengetahui pengaruh atribut produk, kesadaran lingkungan, biaya penggunaan pupuk dan norma subyektif terhadap sikap pembelian serta untuk mengetahui pengaruh sikap pembelian, norma subyektif dan biaya penggunaan pupuk terhadap niat beli pupuk petroganik.

Pupuk petroganik merupakan pupuk yang berbahan baku pupuk kandang, limbah industri dan limbah kota yang bermanfaat untuk memperbaiki struktur dan tata udara tanah, meningkatkan daya sangga air tanah, menjadi penyangga unsur hara dan sesuai untuk semua jenis tanaman (Petrokimia Gresik, 2015).

Perilaku konsumen merupakan semua kegiatan serta proses psikologis yang mendorong tindakan ketika hendak membeli, ketika membeli, menggunakan dan kegiatan evaluasi terhadap produk (Sumarwan, 2003) yang dapat digunakan pemasar untuk merancang bauran pemasaran, segmentasi pasar, positioning dan menciptakan produk baru (Setiadi, 2013).

Theory of Planned Behavior (TPB) merupakan teori yang menjelaskan niat individu dalam berperilaku yang dipengaruhi oleh 3 variabel yaitu sikap, norma subyektif dan kontrol perilaku yang dirasakan (Jogiyanto, 2007).

Niat Perilaku merupakan kecenderungan individu untuk melakukan atau tidak melakukan suatu perilaku (Ajzen, 1991). Sikap terhadap pembelian merupakan derajad evaluasi individu yang menyenangkan atau tidak menyenangkan terhadap suatu perilaku yang dipermasalahkan (Ajzen, 1991).

Norma subyektif merupakan pandangan individu terhadap pandangan orang lain yang dapat mempengaruhi niat seseorang dalam berperilaku (Jogiyanto, 2007). Atribut produk merupakan unsur-unsur penting dan dijadikan dasar pengambilan keputusan pembelian oleh konsumen (Tjiptono, 1995) meliputi merk, mutu, ciri-ciri, desain, label dan kemasan produk (Simamora, 2000).

Kesadaran terhadap lingkungan merupakan keadaan tergugahnya jiwa terhadap sesuatu untuk melestarikan lingkungan (Neolaka dalam Margiyanti, 2013). Faktor produksi merupakan faktor-faktor yang dikorbankan untuk menghasilkan produksi. Faktor-faktor produksi pertanian antara lain 
lahan pertanian, tenaga kerja, modal dan manajemen (Soekartawi, 2003).

Biaya merupakan sejumlah uang yang dikeluarkan untuk membuat barang atau jasa (Hanggana, 2009). Biaya penggunaan pupuk merupakan sejumlah biaya yang dikeluarkan petani dalam menggunakan pupuk petroganik seperti jumlah pupuk, tenaga kerja dan manajemen.

\section{METODE PENELITIAN}

Metode dasar yang digunakan dalam penelitian ini adalah explanatory, yaitu penelitian yang bertujuan untuk mendapatkan penjelasan mengenai hubungan antar variabel melalui pengujian hipotesis (Solimun, 2011). Penelitian dilakukan dengan teknik survei yaitu mengambil sampel dari suatu populasi dengan menggunakan kuisioner (Singarimbun dan Effendi, 1995). Pengambilan data dilakukan dengan teknik multiple cross design yaitu mengambil dua atau lebih sampel dari satu populasi dan informasi yang diambil satu kali dari masing-masing sampel (Sarwono, 2005). Pengambilan data dilakukan dengan wawancara yang di laksanakan pada bulan Juli sampai Agustus 2016.

Penentuan lokasi penelitian dilakukan dengan sengaja (purposive) dengan kriteria kecamatan di Kabupaten Boyolali yang memiliki penjualan pupuk petroganik tertinggi dan terendah. Penarikan sampel dilakukan secara bertahap (multistage random sampling). Sampel yang digunakan dalam penelitian ini berjumlah 64 responden yang terbagi di 2 kecamatan, 4 desa dan 8 kelompok tani. Untuk mengetahui pengaruh antar variabel dilakukan analisis data menggunakan Partial Least Square (PLS) dengan bantuan software smartPLS 3.0.

Tahapan pertama yang dilakukan dalam analisis PLS adalah dengan melakukan pengujian instrumen. Pengujian instrumen dilakukan pada 30 responden. Hasil pengujian intrumen diperoleh hasil bahwa instrumen yang valid dan reliabel dalam kuisioner yang digunakan menggunakan 64 variabel dengan 26 indikator.

\section{HASIL DAN PEMBAHASAN}

\section{Kondisi Umum Lokasi Penelitian}

Kabupaten Boyolali merupakan salah satu dari 35 kabupaten atau kota yang berada di Provinsi Jawa Tengah. Kabupaten Boyolali terletak antara $110^{\circ} 22^{\prime}-110^{\circ} 50^{\prime}$ Bujur Timur dan $7^{\circ} 7^{\prime}$ - $7^{\circ} 36^{\prime}$ Lintang Selatan, dengan ketinggian 75 1500 meter diatas permukaan laut. Kabupaten Boyolali memiliki 19 kecamatan dan lokasi penelitian ini khususnya dilakukan di Kecamatan Nogosari dan Kecamatan Musuk.

Kecamatan Nogosari terletak pada ketinggian 100 - 400 meter diatas permukaan laut, dengan luas wilayah 5.508,43 Ha yang terbagi dalam lahan sawah, pekarangan atau bangunan, tegalan dan lainnya. Jenis tanah di Kecamatan Nogosari merupakan tanah asosiasi grumosol dengan struktur tanah berlempung. Kecamatan Musuk terlatak pada ketinggian 700 meter diatas permukaan laut dengan suhu maksimum $33^{\circ} \mathrm{C}$ dan suhu minimum $18^{\circ} \mathrm{C}$. Kecamatan musuk memiliki luas wilayah $6.504,1391 \mathrm{Ha}$ yang terbagi dalam pekarangan atau bangunan, tegal atau kebun, padang gembala, hutan negara dan lainnya. Jenis tanah di Kecamatan Musuk terdiri dari jenis tanah litosol, regosol kelabu dan regosol cokelat dengan struktur tanah berpasir.

\section{Gambaran Umum Penggunaan Pupuk Petroganik di Kabupaten Boyolali}

Penggunaan pupuk petroganik di Kabupaten Boyolali di awali dengan sosialisasi yang dilaksanakan oleh pemerintah terkait kebijakan untuk menggunakan pupuk organik. Hal ini bertujuan untuk mengurangi penggunaan dan pembelian pupuk anorganik dan meningkatkan kesadaran petani terhadap pentingnya manfaat pupuk organik. Sosialisasi yang dilaksanakan oleh pemerintah tidak berjalan lama dan sekarang sosialisasi tersebut sudah tidak berjalan. Hal tersebut terjadi karena sebagian petani merasa keberatan dengan sistem penjualan tersebut. Pada saat ini petani yang merasakan dampak penggunaan pupuk petroganik terus melakukan pembelian dan petani yang tidak menyukai enggan untuk melakukan pembelian,hal tersebut berdampak pada penjualan pupuk petroganik yang mengalami fluktuatif. 


\section{Karakteristik Responden}

1. Karakteristik Petani Berdasarkan Tingkat Pendidikan

Tabel 1. Karakteristik Petani Responden Berdasarkan Tingkat Pendidikan

\begin{tabular}{clcc}
\hline No & $\begin{array}{l}\text { Tingkat } \\
\text { Pendidikan }\end{array}$ & $\begin{array}{c}\text { Jumlah } \\
\text { Jiwa } \\
\text { (Orang) }\end{array}$ & $\begin{array}{c}\text { Persentase } \\
(\%)\end{array}$ \\
\hline 1 & Tidak Sekolah & 2 & 3,12 \\
2 & SD & 26 & 40,63 \\
3 & SMP & 21 & 32,81 \\
4 & SMA & 12 & 18,75 \\
5 & Sarjana & 3 & 4,69 \\
6 & Master & 0 & 0,00 \\
\hline & Total & 64 & 100,00 \\
\hline
\end{tabular}

Sumber : Data Primer Diolah, 2016

Tingkat pendidikan petani responden didominasi oleh petani yang menyelesaikan tingkat pendidikan SD yaitu $40,63 \%$ dari total responden atau berjumlah 26 orang.Pendidikan petani yang sebagian besar rendah disebabkan oleh beberapa hal, antara lain pada zaman dahulu sarana dan prasarana yang belum memadai, terbatasnya jumlah sekolah, kondisi sosial ekonomi masyarakat pedesaan yang rendah sehingga lebih memilih mengikuti orang tua untuk bekerja di ladang yang berakibat kurang memperhatikan pentingnya pendidikan.

2. Karakteristik Petani Berdasarkan Usia

Tabel 2. Karakteristik Petani Berdasarkan Usia

\begin{tabular}{cccc}
\hline No & $\begin{array}{c}\text { Usia } \\
\text { (Tahun) }\end{array}$ & $\begin{array}{c}\text { Jumlah Jiwa } \\
\text { (Orang) }\end{array}$ & $\begin{array}{c}\text { Persentase } \\
(\%)\end{array}$ \\
\hline 1 & $20-29$ & 0 & 0,00 \\
2 & $30-39$ & 6 & 9,37 \\
3 & $40-49$ & 16 & 25,00 \\
4 & $50-59$ & 28 & 43,75 \\
5 & $60-69$ & 12 & 18,75 \\
6 & 70 keatas & 2 & 3,13 \\
\hline \multicolumn{2}{c}{ Total } & 64 & 100,00 \\
\hline
\end{tabular}

Sumber: Data Primer Diolah, 2016

Usia responden dikategorikan dalam kisaran 10 tahun. Hasil penelitian menunjukkan bahwa petani responden sebagian besar berusia 50-59 tahun yang berjumlah 28 orang atau $43.75 \%$ dari total responden. Usia petani yang menjadi responden termasuk dalam kategori usia yang produktif untuk bekerja yaitu usia 15 sampai 64 tahun. Usia petani responden yang tergolong pada tenaga kerja produktif mengindikasikan petani masih memiliki semangat kerja yang lebih besar dibandingkan dengan petani yang berusia dalam kategori non produktif. Sehingga usia produktif lebih berpotensi meningkatkan atau menggunakan inovasi dalam berusaha tani.

3. Karakteristik Petani Berdasarkan Pengalaman Berusahatani

\begin{tabular}{|c|c|c|c|}
\hline Tabel & \multicolumn{2}{|c|}{$\begin{array}{l}\text { Karakteristik Petani } \\
\text { Pengalaman Berusahatani }\end{array}$} & Berdasarkan \\
\hline No & Lama & Jumlah & Persentase \\
\hline & $\begin{array}{l}\text { Berusahatani } \\
\text { (Tahun) }\end{array}$ & $\begin{array}{l}\text { Jiwa } \\
\text { (Orang) }\end{array}$ & \\
\hline 1 & $<10$ & 0 & 0,00 \\
\hline 2 & $10-19$ & 11 & 17,19 \\
\hline 3 & $20-29$ & 11 & 17,19 \\
\hline 4 & $30-39$ & 25 & 39,06 \\
\hline 5 & $40-49$ & 15 & 23,43 \\
\hline 6 & 50 keatas & 2 & 3,13 \\
\hline & Total & 64 & 100,00 \\
\hline
\end{tabular}

Sumber: Data Primer Diolah, 2016

Pengalaman berusahatani diperlukan untuk menambah wawasan dan pengetahuan dalam berusahatani. Hasil penelitian menunjukkan bahwa sebagian besar petani responden memiliki pengalaman berusahatani 30-39 tahun yang berjumlah 25 orang atau $39.09 \%$ dari total responden. Petani yang memiliki pengalaman berusahatani yang lebih lama mengindikasikan memiliki informasi dan pengetahuan yang lebih banyak dan lebih baik, sehingga lebih mahir dalam berusahatani.

Analisis Pengaruh Sikap, Norma Subyektif dan Kontrol Perilaku yang Dirasakan Terhadap Niat Beli Pupuk Petroganik

1. Analisis Structural Equation Modelling

a. Pengujian Model Pengukuran (Outer Model)

1) Uji Validitas Konvergen

Uji validitas konvergen digunakan untuk mengetahui hubungan indikator dengan variabel laten yang diukur.

Indikator-indikator dalam variabel laten yang sama harus berkorelasi yang ditunjukkan oleh nilai loading factor $>0.5$ (Ghozali, 2011). Hasil pengujian validitas konvergen diperoleh nilai loading factor > 0.5 kecuali 6 indikator yaitu AP1, AP2, BP3, BP4, NS2 dan NS4 dan indikator 
tersebut harus dihilangkan karena tidak valid.

2) Uji Validitas Diskriminan

Uji validitas diskriminan digunakan untuk mengetahui hubungan indikator dalam menjelaskan variabel latennya dibandingkan menjelaskan variabel laten yang lain.

Tabel 4. Hasil Uji Model PengukuranValiditas Diskriminan

\begin{tabular}{ccc}
\hline & AVE & Keterangan \\
\hline AP & 0 & Valid \\
KL & 6 & Valid \\
BP & 16 & Valid \\
SP & 28 & Valid \\
NS & 12 & Valid \\
NP & 2 & Valid \\
\hline
\end{tabular}

Sumber: Data Primer Diolah, 2016

Indikator variabel laten dalam menjelaskan hubungannya harus lebih baik dibandingkan menjelaskan variabel laten yang lain. Uji validitas diskriminan dikatakan valid valid jika memiliki nilai AVE > 0.5 (Solimun, 2011). Hasil uji model pengukuan validitas diskriminan pada masing-masing variabel memiliki nilai AVE > 0,5, hal ini berarti masingmasing variabel dinyatakan valid dan indikator dalam menjelaskan variabel latennya lebih baik dibandingkan dengan menjelaskan variabel laten yang lain.

3) Uji Reliabilitas

Uji reliabilitas digunakan untuk mengukur konsistensi dan ketepatan alat ukur dalam melakukan pengukuran. Hasil pengujian reliabilitas dapat dilihat pada Tabel 5 .

Tabel 5. Hasil Uji Model Pengukuran Reliabilitas Komposit

\begin{tabular}{ccl}
\hline & $\begin{array}{c}\text { Composite } \\
\text { Reliability }\end{array}$ & Keterangan \\
\hline AP & 0.856 & Reliabel \\
KL & 0.842 & Reliabel \\
BP & 0.859 & Reliabel \\
SP & 0.837 & Reliabel \\
NS & 0.869 & Reliabel \\
NP & 0.928 & Reliabel \\
\hline
\end{tabular}

Sumber : Data Primer Diolah, 2016

Hasil pengujian reliabilitas dikatakan reliabel jika nilai composite reliability> 0.7 (Solimun, 2011). Hasil pengujian diperoleh hasil bahwa masing-masing variabel laten memiliki nilai composite reliability> 0.7 , hal ini berarti variabel yang digunakan telah reliabel. Berdasarkan pada hasil pengujian pengukuran (outer model) maka instrumen yang digunakan dalam penelitian ini terdiri dari 6 variabel laten dengan 20 indikator.

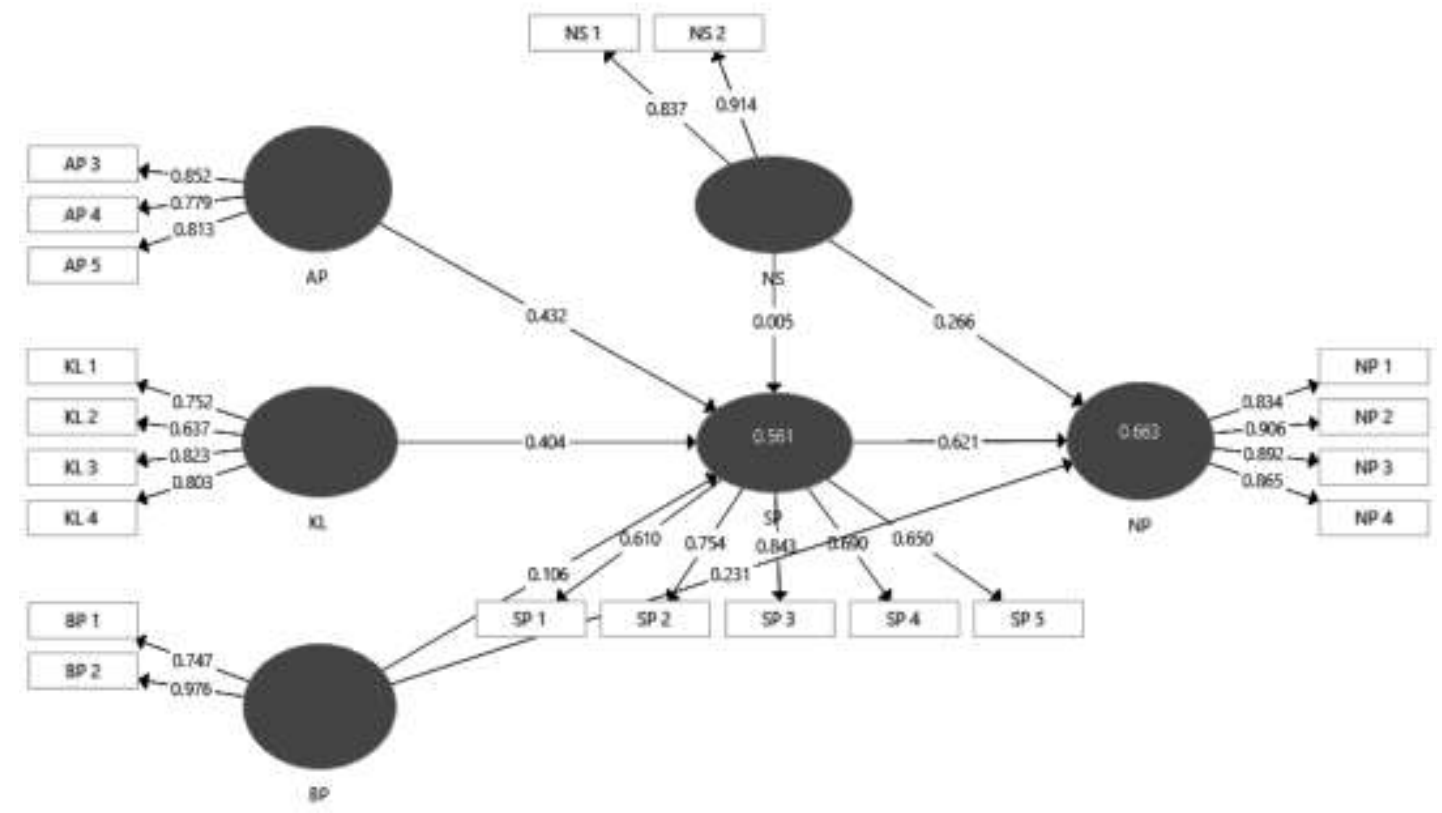

Gambar 1. Hasil Ouput PLS - Pengujian Pengukuran dan Pengujian Struktural 
b. Pengujian Model Struktural Pengujian model struktural digunakan untuk mengetahui hubungan antar variabel laten dan mengukur seberapa baik model yang digunakan. Hasil pengujian inner model termuat pada Tabel 6 .

Tabel 6. Hasil Uji Model Struktural

\begin{tabular}{ccc}
\hline & R Square & Keterangan \\
\hline $\mathrm{SP}$ & 0.561 & Sedang \\
$\mathrm{NP}$ & 0.663 & Sedang \\
$($ Q Square $)$ & 0.616 & \\
\hline
\end{tabular}

Sumber: Data Primer Diolah dengan PLS, 2016

Hasil pengujian model struktural diperoleh hasil bahwa masing-masing variabel sikap pembelian (SP) dan niat pembelian (NP) termasuk pada kategori yang sedang. Sikap pembelian dipengaruhi oleh atribut produk, kesadaran lingkungan, norma subyektif dan biaya penggunaan pupuk sebesar $56.1 \%$, sedangkan niat pembelian dipengaruhi oleh sikap pembelian, biaya penggunaan pupuk dan norma subyektif sebesar $66.3 \%$. Nilai predictive relevance ( $Q$ square) sebesar 0.616 yang berarti bahwa model yang digunakan untuk mengukur niat beli pupuk petroganik adalah baik.

\section{Pengujian Hipotesis}

Pengujian hipotesis menggunakan analisis boots trapping pada software smart PLS 3.0. Hasil pengujian hipotesis termuat pada Tabel 7.

\section{H1: atribut produk diduga berpengaruh} terhadap sikap pembelian

Hasil pengujian hipotesis 1 bahwa atribut produk terhadap sikap pembelian memiliki nilai original sampel sebesar 0.432 dan nilai $p$-value sebesar 0.000. Hal ini berarti hipotesis 1 memiliki arah yang positif dan signifikan pada taraf signifikansi $1 \%$. Dengan demikian hipotesis 1 pada penelitian ini diterima. Maka dapat disimpulkan bahwa atribut produk (AP) berpengaruh positif terhadap sikap pembelian (SP), artinya semakin tinggi persepsi petani terhadap kelengkapan atribut produk pupuk petroganik, maka akan meningkatkan sikap pembelian terhadap pupuk petroganik.

Hasil pengujian hipotesis $\left(\mathrm{H}_{1}\right)$ pada penelitian ini sesuai dan mendukung hasil penelitian yang dilakukan oleh Irianto (2015) dan Astuti, Asmara dan Rahayu (2010). Atribut produk merupakan salah satu hal yang di pertimbangakan oleh petani dalam menyukai pupuk petroganik. Atribut produk pupuk petroganik yang lengkap dan sesuai dengan kebutuhan akan menjadi daya tarik petani untuk menyukai pupuk petroganik.

Tabel 7. Hasil Uji Hipotesis

\begin{tabular}{lccll}
\hline & $\begin{array}{c}\text { Original Sample } \\
(\mathrm{O})\end{array}$ & $\begin{array}{c}\text { T Statistic } \\
(\mid \mathrm{O} / \mathrm{STDEV})\end{array}$ & \multicolumn{1}{c}{ P Value } & Keterangan \\
\hline $\mathrm{AP} \rightarrow \mathrm{SP}$ & 0.432 & 4.824 & $\left.0.000^{* * *}\right)$ & Signifikan \\
$\mathrm{KL} \rightarrow \mathrm{SP}$ & 0.404 & 4.274 & $0.000^{* * *)}$ & Signifikan \\
$\mathrm{BP} \rightarrow \mathrm{SP}$ & 0.106 & 1.087 & $0.278^{* *)}$ & Tidak signifikan \\
$\mathrm{BP} \rightarrow \mathrm{NP}$ & 0.231 & 2.500 & $0.013^{* * *}$ & Signifikan \\
$\mathrm{SP} \rightarrow \mathrm{NP}$ & 0.621 & 8.623 & $0.000^{* * *}$ & Signifikan \\
$\mathrm{NS} \rightarrow \mathrm{SP}$ & 0.005 & 0.044 & 0.965 & Tidak signifikan \\
$\mathrm{NS} \rightarrow \mathrm{NP}$ & 0.266 & 3.072 & $0.002^{* * *)}$ & Signifikan \\
\hline
\end{tabular}

Sumber: Data Primer Diolah dengan PLS, 2016

Keterangan :

AP : Atribut Produk

KL : Kesadaran Lingkungan

BP : Biaya Penggunaan Pupuk

SP : Sikap Pembelian

NS : Norma Subyektif

NP : Niat Pembelian

$* * *)$ : Signifikan pada $\alpha=0.01$

**) : Signifikan pada $\alpha=0.05$

*) : Signifikan pada $\alpha=0.1$ 
Pupuk petroganik dapat menggemburkan tanah, sehingga dapat memperbaiki sifat fisik, kimia dan biologi tanah, dapat meningkatkan berat isi pada bulir padi, hasil produksi lebih baik dan lebih sehat meruapak alasan petani menyukai atribut produk pupuk petroganik.

\section{H2: kesadaran lingkungan diduga berpengaruh positif terhadap sikap pembelian}

Hasil pengujian hipotesis 2 bahwa kesadaran lingkungan terhadap sikap pembelian memiliki nilai original sampel sebesar 0.404 dan nilai $p$ value sebesar 0.000 . Hal ini berarti hipotesis 2 memiliki arah jalur yang positif dan signifikan pada taraf signifikansi $1 \%$. Dengan demikian hipotesis 2 pada penelitian diterima. Maka dapat disimpulkan bahwa semakin meningkatnya kesadaran petani terhadap lingkungan akan meningkatkan sikap pembelian terhadap pupuk petroganik.

Hal ini sesuai dengan penelitian yang dilakukan oleh Astuti, et al. (2010) yang menjelaskan bahwa salah satu keyakinan petani dalam memilih pupuk organik kemasan karena pupuk organik merupakan pupuk yang ramah lingkungan dan memiliki keamanan bagi tanah dan lingkungan dalam penggunaannya. Irianto dan Haryanto (2011) serta Margiyanto (2013) menyimpulkan bahwa kesadaran individu terhadap lingkungan dapat meningkatkan niat dan perilaku individu dalam melakukan kegiatan yang berkaitan dengan menjaga lingkungan. Petani memiliki kesadaran bahaya penggunaan pupuk anorganik dan merasakan kondisi tanah yang sulit diolah menyebabkan petani menyukai pupuk petroganik untuk dapat digunakan dalam masa tanam. Petani yakin pupuk petroganik merupakan pupuk yang ramah lingkungan yang dapat memperbaiki tanah dan baik untuk kondisi lingkungan.

\section{H3: biaya penggunaan pupuk diduga berpengaruh negatif terhadap sikap pembelian}

Hasil pengujian hipotesis 3 bahwa biaya penggunaan pupuk terhadap sikap pembelian memiliki nilai original sampel sebesar 0.106 dan nilai $p$-value sebesar 0.278 . Hal ini berarti hipotesis 3 pada penelitian ini tidak signifikan pada taraf signifikansi $1 \%, 5 \%$ maupun $10 \%$, dengan demikian hipotesis 3 pada penelitian ini ditolak. Maka dapat disimpulkan bahwa biaya penggunaan pupuk (BP) tidak berpengaruh terhadap sikap pembelian (SP), artinya semakin meningkat biaya penggunaan pupuk tidak berpengaruh terhadap sikap pembelian pupuk petroganik.

Hasil penelitian ini sesuai dengan penelitian yang dilakukan oleh Irianto dan Haryanto (2011) yang menyimpulkan bahwa kontrol perilaku yang dirasakan tidak berpengaruh terhadap sikap pembelian. Variabel biaya penggunaan pupuk digunakan untuk mengukur variabel kontrol perilaku yang dirasakan. Biaya pengunaan pupuk tidak berpengaruh terhadap sikap pembelian pupuk petroganik dikarenakan dalam menyukai atau tidak menyukai pupuk petroganik biaya belum di perhitungkan oleh petani. Petani lebih memperhatikan atribut produk dan kesadaran dalam menjaga lingkungan untuk menyukai pupuk petroganik.

\section{H4: biaya penggunaan pupuk diduga berpengaruh negatif terhadap niat pembelian}

Hasil pengujian hipotesis 4 bahwa biaya penggunaan pupuk terhadap niat pembelian memiliki nilai original sampel sebesar 0.231 dan nilai $p$-value sebesar 0.013 . Hal ini berarti hipotesis 4 signifikan pada taraf signifikansi 5\%. Dengan demikian hipotesis 4 pada penelitian ini diterima. Maka dapat disimpulkan bahwa biaya penggunaan pupuk (BP) berpengaruh terhadap niat pembelian (NP), artinya persepsi petani terhadap biaya penggunaan pupuk yang semakin tinggi, akan berpengaruh terhadap niat pembelian pupuk petroganik.

Hasil penelitian ini sesuai dan sejalan dengan penelitian yang dilakukan oleh Sugiarto dan Subagio (2015) yang menyatakan bahwa harga berpengaruh terhadap niat beli konsumen di Dream of Kahyangan Art Resto Surabaya. Dalam beberapa penelitian kontrol perilaku yang dirasakan berpengaruh terhadap niat pembelianantara lain Irianto dan Haryanto (2011) dan Istiana, Syahlani dan Nurtini (2009). Dalam penelitian ini biaya penggunaan pupuk tidak berpengaruh terhadap sikap pembelian namun berpengaruh terhadap niat pembelian, hal ini dikarenakan dalam menyukai atau tidak menyukai pupuk petroganik petani belum memperhitungkan biaya, namun ketika petani berniat untuk 
membeli pupuk petorganik, petani memperhitungkan biaya yang akan dikeluarkan, karena biaya berpengaruh pada pendapatan dan keuntungan.

\section{H5 : sikap pembelian diduga berpengaruh} positif terhadap niat pembelian

Hasil pengujian hipotesis 5 bahwa sikap pembelian terhadap niat pembelian memiliki nilai original sampel sebesar 0.621 dan nilai $p$ value sebesar 0.000 . Hal ini berarti hipotesis 5 memiliki arah yang positif dan signifikan pada taraf signifikansi \%. Dengan demikian hipotesis 5 pada penelitian ini diterima. Maka dapat disimpulkan bahwa sikap pembelian (SP) berpengaruh positif terhadap niat pembelian (NP), artinya semakin petani menyukai pembelian pupuk petroganik, petani akan meningkatkan niat pembelian terhadap pupuk petroganik.

Hasil penelitian ini sesuai dan mendukung penelitian yang dilakukan oleh Tarkianen dan sundqvist (2005) dan Irianto dan Haryanto (2011) bahwa sikap individu berpengaruh terhadap niat individu dalam berperilaku. Petani berkeyakinan bahwa atribut produk pupuk petroganik baik dan sesuai dengan kebutuhan, sehingga petani menyukai pembelian pupuk petroganik, dengan demikian petani memiliki niat untuk membeli pupuk petroganik.

H6: norma subyektif diduga berpengaruh positif terhadap sikap pembelian

Hasil pengujian hipotesis 6 bahwa norma subyektif terhadap sikap pembelian memiliki nilai original sampel sebesar 0.005 dan nilai $p$ value sebesar 0.965 . Hal ini berarti hipotesis 6 pada penelitian ini tidak signifikan pada taraf signifikansi $1 \%, 5 \%$ dan $10 \%$, dengan demikian hipotesis 6 pada penelitian ini ditolak. Maka dapat disimpulkan bahwa norma subyektif (NS) tidak berpengaruh terhadap sikap pembelian (SP), artinya semakin meningkat pandangan petani terhadap pandangan orang lain, tidak berpengaruh terhadap sikap pembelian petani terhadap pupuk petroganik.

Hasil penelitian ini tidak sesuai dengan penelitian yang dilakukan oleh Irianto dan Haryanto (2011). Hal ini terjadi disebabkan karena dalam menyukai atau tidak menyukai pupuk petroganik, pandangan orang lain belum maksimal dalam mempengaruhi perasaan petani. Selera dan pandangan petani itu sendiri yang mempengaruhi sikap petani dalam pembelian pupuk petroganik. Dalam penelitian ini sikap petani dalam menyukai pupuk petroganik lebih dipengaruhi oleh atribut produk dan kesadaran yang dimiliki petani terhadap lingkungan.

\section{H7: norma subyektif diduga berpengaruh positif terhadap niat pembelian}

Hasil pengujian hipotesis 7 bahwa norma subyektif terhadap niat pembelian memiliki nilai original sampel sebesar 0.266 dan nilai $p$ value 0.002 . Hal ini berarti hipotesis 7 memiliki arah yang positif dan sinifikan pada taraf signifikansi $1 \%$. Dengan demikian hipotesis 7 pada penelitian ini diterima. Maka dapat disimpulkan bahwa norma subyektif (NS) berpengaruh positif terhadap niat pembelian (NP), artinya semakin meningkat pandangan petani terhadap pandangan orang lain tetang pupuk petroganik, akan meningkatkan niat pembelian pupuk petroganik.

Hasil penelitian ini sesuai dan mendukung penelitian yang dilakukan oleh Irianto dan Haryanto (2011) dan Astuti, Asmara dan Rahayu (2010) bahwa norma subyektif berpengaruh terhadap niat individu dalam berperilaku. Dalam penelitian ini norma subyektif tidak berpengaruh terhadap sikap pembelian, namun berpengaruh terhadap niat pembelian, hal ini terjadi disebabkan oleh penilaian petani terhadap pupuk petroganik lebih didominasi oleh atribut produk dibandingkan apresiasi atau pandangan referensi, namun pandangan orang lain mampu mempengaruhi niat beli petani disebabkan oleh dalam budidaya petani mengikuti kondisi lingkungan.

\section{KESIMPULAN DAN SARAN}

\section{Kesimpulan}

Hasil penelitian tentang niat beli pupuk petroganik di Kabupaten Boyolali dapat disimpulkan bahwa :

1. Atribut produk berpengaruh positif terhadap sikap pembelian pupuk petroganik

2. Kesadaran lingkungan berpengaruh positif terhadap sikap pembelian pupuk petroganik 
3. Biaya penggunaan pupuk tidak berpengaruh terhadap sikap pembelian pupuk petroganik

4. Biaya penggunaan pupuk berpengaruh positif terhadap niat pembelian pupuk petroganik

5. Sikap pembelian berpengaruh positif terhadap niat pembelian pupuk petroganik

6. Norma subyektif tidak berpengaruh terhadap sikap pembelian pupuk petroganik

7. Norma subyektif berpengaruh positif terhadap niat pembelian pupuk petroganik

\section{Saran}

Saran yang dapat diberikan dari penelitian ini antara lain:

1. Produsen hendaknya mempertahankan atribut produk yang ditawarkan untuk lebih meyakinkan petani bahwa pupuk petroganik merupakan pupuk yang ramah lingkungan dan bermanfaat bagi tanah dan tanaman, karena hal tersebut yang mendasari petani bersikap positif terhadap pembelian pupuk petroganik.

2. Penetapan kembali harga dengan atribut yang ditawarkan hendaknya di pertimbangkan ulang karena penggunaan pupuk petroganik dalam budidaya diperlukan jumlah karung pupuk petroganik yang lebih banyak sehingga berakibat pada biaya penggunaan pupuk petroganik lebih mahal dibandingkan penggunaan pupuk anorganik.

3. Sebaiknya dilakukan sosialisasi tentang manfaat penggunaan pupuk petroganik dalam budidaya, untuk meningkatkan informasi dan pengetahuan petani yang dapat dilakukan melalui penyuluhan pertanian dengan menghadirkan petani yang telah sukses dalam menerapkan pupuk pertoganik dalam budidayanya,hal ini ditujukan untuk memberi motivasi atau pengaruh kepada petani, membuat desa binaan penggunaan pupuk petroganik untuk membuktikan manfaat pupuk petroganik agar petani lebih yakin terhadap pupuk petroganik dan dapat meningkatkan niat pembelian pupuk petroganik.

\section{DAFTAR PUSTAKA}

Ajzen, I. 1991. The Theory of Planned Behavior. Organizational Behavior And Human Decision Processes. 50: 179-211

Astuti, D. R, Asmara, R. dan Rahayu P. 2010. Analisis Sikap dan Norma Subyektif Sebagai Faktor Yang Mempengaruhi Keputusan Pembelian Petani Terhadap Pupuk Organik Kemasan. Jurnal Agrise, $\mathrm{X}(2)$ : 87-97.

Elviwirda. 2015. Potensi Bahan Organik Dalam Meningkatkan Produktivitas Lahan. Framework

Ghozali, I. 2011. Structural Equation Modeling Metode Alternatif dengan Partial Least Square (PLS). Badan Penerbit Undip. Semarang.

Hanggana, S. 2009. Akuntansi Biaya Teori dan Aplikasi. UNS Press. Surakarta.

Irianto, $\mathrm{H}$ dan Haryanto, B. 2011. Niat Konsumen Dalam Pembelian Makanan Organik. Jurnal Kinerja Bisnis dan Ekonomi, 15(1): 73-87.

Irianto, H. 2015. Consumers' Attitude And Intention Towards Organic Food Purchase : An Extention Of Theory Of Planned Behavior In Gender Perspective. International Journal of Management, Economics and Social Sciences (IJMESS), 4 (1): 17-31.

Jogiyanto. 2007. Sistem informasi keperilakuan. Andi Offset. Yogyakarta.

Margiyanti, E. 2013. Pengaruh Kesadaran Lingkungan Terhadap Niat Beli Produk Hijau. Naskah Publikasi.Universitas Muhammadiyah Surakarta. Surakarta.

Petrokimia Gresik. 2015. Pupuk Petroganik Petrokimia Gresik.http:// www. petrokimia-gresik.com/Pupuk/ Petroganik. diakses pada tanggal 14 oktober 2015.

PT Pupuk Indonesia. 2015.Data Pemasaran Pupuk bersubsidi PT Pupuk indonesia. http://pupuk- 
indonesia.com/id/pemasaran/datapemasaran/pupuk/subsidi. Diakses pada 24 November 2015.

Purna, I. 2010. Pertanian Go Organic. http://www.setneg.go.id diakses pada tanggal 25 Februari 2016.

Sarwono, J. 2005. Teori dan Praktik Riset Pemasaran dengan SPSS. Andi Offset. Yogyakarta.

Setiadi. 2013. Perilaku Konsumen Perspektif Kontemporer Pada Motif, Tujuan, Dan Keinginan Konsumen. Cetakan Ke 5. Kencana Prenada Media Group. Jakarta.

Simamora, H. 2000. Manajemen Pemasaran Internasional. Salemba Empat. Jakarta

Singarimbun, M. dan Sofian, E. 1995. Metode Penelitian Survei. LP3ES. Jakarta.

Soekartawi.2003. Teori Ekonomi Produksi dengan Pokok Bahasan Analisis Fungsi Cobb-Douglas. PT Raja Grafindo Persada. Jakarta
Solimun. 2011. Analisis Multivariat Pemodelan Struktural Metode Partial Least SquarePLS. Penerbit CV Citra Malang. Malang.

Sugiarto Budi U dan Subagio H. 2014. Analisa Pengaruh Produk, Kualitas Pelayanan, Harga dan Store Atmosphere Terhadap Minat Beli Di Dream of Khayangan Art Resto Surabaya. Jurnal Manajemen Pemasaran Petra, 2 (1): 1-14.

Sumarwan, U. 2003. Perilaku Konsumen Teori dan Penerapannya dalam Pemasaran. Ghalia Indonesia. Jakarta.

Sutanto, R 2002. Pertanian Organik Menuju Pertanian Alternatif dan Berkelanjutan. Kanisius. Yogyakarta.

Tarkiainen, A dan Sundqvist, S. 2005. Subjective norms, attitudes and intentions of Finnish consumers in buying organic food. British Food Journal, 107 (11): 808 - 822.

Tjiptono, F. 1995. Strategi Pemasaran. Andi Offset. Yogyakarta. 